\title{
UPAYA MENINGKATKAN KEMAMPUAN HUBUNGAN SOSIAL MAHASISWA PROGRAM STUDI BIMBINGAN DAN KONSELING IKIP-PGRI PONTIANAK
}

\author{
Kamaruzzaman $^{1}$, Hendra Sulistiawan ${ }^{2}$, Aliwanto $^{3}$ \\ ${ }^{1,2,3}$ Program Studi Bimbingan dan Konseling \\ Fakultas Ilmu Pendidikan dan Pengetahuan Sosial IKIP PGRI Pontianak \\ Jalan Ampera Nomor 88 Pontianak - 78116, Telepon (0561) 748219 Fax. (0561) 589855 \\ ${ }^{1}$ Alamat e-mail: oranecorby@gmail.com
}

\begin{abstract}
Abstrak
Penelitian ini dilakukan pada mahasiswa Program Studi Bimbingan dan Konseling IKIP-PGRI Pontianak Tahun Akademik 2016/2017. Penelitian ini bertujuan untuk meningkatkan kemampuan hubungan sosial melalui layanan bimbingan kelompok pada mahasiswa. Metode yang digunakan dalam penelitian adalah metode deskriptif dengan bentuk penelitian tindakan bimbingan dan konseling. Teknik pengumpul data yang digunakan adalah teknik observasi langsung dan teknik komunikasi tidak langsung dengan alat pengumpul data berupa pedoman observasi, dan angket. Subjek penelitian ini adalah semua 23 orang siswa. Hasil dari penelitian ini menunjukkan bahwa layanan bimbingan kelompok untuk meningkatkan hubungan sosial pada mahasiswa IKIP-PGRI Pontianak telah dilaksanakan dan berhasil dengan baik.
\end{abstract}

Kata Kunci: Hubungan Sosial, Bimbingan Kelompok

\section{Abstract}

This research was conducted on students of Program Studi Bimbingan Konseling IKIP-PGRI Pontianak Academic Year 2016/2017. This research aims to improve the ability of social relations through group guidance services for colllege students. The method used in the research is descriptive method with the form of guidance and counseling action research. Data collection techniques used are direct observation techniques and indirect communication techniques with data collection tools in the form of observation guidelines, and questionnaires. The subjects of this research were all 23 students. The results of this research indicate that group guidance services to improve social relations in IKIP-PGRI Pontianak students have been carried out and have been successful.

Keyword : Social Relations, Group Guidance

\section{PENDAHULUAN}

Pendidikan merupakan usaha bersama untuk mengembangkan potensi yang ada pada diri siswa, agar mampu hidup secara mandiri. Untuk itu diperlukan berbagai kemampuan dalam mengembangkan aspek kognitif, afektif dan psikomotorik. Demikian halnya peran siswa sebagai mahkluk sosisal akan selalu dikembangkan untuk mampu menjalin dan mengembangkan hubungan sosial dengan baik. Abu Ahmadi (2003:117) mengemukakan individu sebagai makhluk sosial akan selalu berinteraksi dengan lingkungannya. Objek sosial ini akan 
berpengaruh terhadap perkembangan individu. Melalui pendidikan, dapat dikembangkan suatu keadaan yang seimbang antara perkembangan aspek individual dan aspek sosial. Hubungan sosial yang terjadi di lingkungan pendidikan, sangat membantu individu dalam menambah pengetahuannya, selain pengetahuan pembelajaran yang diperoleh. Hubungan sosial dapat berupa hubungan sesama teman pergaulan, hubungan dengan orang yang lebih tua, hubungan dengan dosen, hubungan dengan staf administrasi dan berbagai pihak lainnya.

Mahasiswa sebagai mahluk sosial, memiliki dorongan ingin tahu, ingin maju dan berkembang, salah satu strateginya melalui hubungan sosial. Hubungan sosial yang diciptakan merupakan kebutuhan yang mutlak bagi kehidupan manusia. Hubungan sosial memberikan sesuatu kepada orang lain dengan kontak tertentu atau dengan mempergunakan sesuatu alat komunikasi. Banyak hubungan sosial yang terjadi dan berlangsung tetapi kadang-kadang tidak tercapai kepada sasaran tentang hubungan apa yang diinginkan. Dimungkinkan adanya komunikasi yang baik antara pemberi pesan dan penerima pesan kalau terjalin persesuaian diantara keduanya. Seseorang dituntut untuk bisa berinteraksi sosial atau hubungan sosial dengan orang lain yang tentunya sesuai dengan nilai-nilai dan norma yang berlaku. Hal ini dilihat penting karena sebagai kontribusi dari hubungan tersebut berdampak positif bagi perkembangannya, yang masa usianya berada pada masa pencarian jati diri. Dengan hubungan sosial seseorang dapat mempelajari sisi kehidupan untuk mencapai kedewasaan, peningkatan kepribadian, peningkatan manajemen diri, dan penyesuaian diri yang baik.

Kenyataan terjadi di lingkungan pandidikan sering ditemukan beberapa permasalahan terkait hubungan sosial diantaranya terdapat individu yang kurang mampu menyesuaikan diri dengan baik, kurang mampu bergaul, suka menyendiri, jarang berkomunikasi, pendiam, kesulitan dalam menjalin hubungan sosial, apalagi mengembangkan hubungan sosial. Kondisi ini terjadi di perguruan tinggi khususnya pada mahasiswa Program Studi Bimbingan dan Konseling IKIPPGRI Pontianak, masih banyak ditemukan beberapa mahasiswa yang kurang memiliki kemampuan dalam menjalin dan mengembangkan hubungan sosial 
seperti kurang baik dalam berkomunikasi dengan orang lain, kurang bergaul, sering menyendiri, berkelompok dalam bermain, kurang menjalin komunikasi dengan orang lain, tidak memiliki kotak sosial.

Masalah ini tentunya bukan masalah yang mudah untuk diatasi, sebagaimana pendapat Sunarto dan Agung Hartono (2002:10) mengemukakan bahwa : upaya untuk dapat mengubah sikap dan perilaku kekanak-kanakan menjadi sikap perilaku dewasa, tidak semua dapat dengan mudah dicapai baik oleh remaja laki-laki maupun remaja perempuan. Oleh karena itu diperlukannya bantuan untuk mengatasi hal tersebut di antaranya memberikan suatu bimbingan.

Menurut Miller Frank W (dalam Prayitno, 2012:7) mengemukakan bahwa "Guidance is the process of helfing individual achieve the self understanding and the self direction necessary to make the information choices and to move toward self-selected goals intelegent or orrecting ways". Artinya: Bimbingan adalah proses membantu individu mencapai pemahaman diri dan arah diri diperlukan untuk membuat aneka pilihan informasi dan untuk bergerak kearah sasaran yang cerdas atau dengan mengorekasi. Sedangkan menurut Kamaruzzaman, 2016:2) mengartikan bimbingan merupakan bantuan yang dilakukan oleh seorang yang memiliki kepribadian, beretika, bermoral, dapat dipercaya, profesional, kepada individu atau peserta didik agar dapat memahami dirinya, potensi dirinya, keadaan orang-orang yang ada di lingkungannya, serta penyesuaian dirinya dalam mencapai perkembangan yang optimal.

Bimbingan kelompok merupakan salah satu layanan dalam bimbingan dan konseling yang memungkinkan siswa menerima berbagai informasi dan bimbingan dalam suasana kelompok. Zainal Aqib (2011:81) mengemukakan bahwa bimbingan kelompok adalah layanan bimbingan dan konseling yang memungkinkan sejumlah peserta didik secara bersama-sama melalui dinamika kelompok memperoleh berbagai bahan dari narasumber tertentu sebagai pertimbangan dalam pengambilan keputusan.

Layanan bimbingan kelompok untuk meningkatkan kemampuan hubungan sosial pada mahasiswa dimaksudkan agar individu tersebut memiliki pandangan hidup sebagai suatu keseluruhan, cenderung bersifat realistis dan objektif terhadap 
diri sendiri maupun orang lain, peduli terhadap faham-faham abstrak seperti keadilan sosial, mampu mengintegrasikan nilai-nilai yang bertentangan, toleran terhadap ambiguitas, peduli akan pemenuhan diri (Self full fillment), ada keberanian untuk menyelesaikan konflik internal, resfek terhadap terhadap sikap orang lain, saling menghormati dan menghargai orang lain, mematuhi serta menjalankan norma dan nilai yang berlaku, serta berinteraksi sosial antara sesama. Melalui layanan bimbingan kelompok mahasiswa dapat berkomunikasi, berinteraksi dan mengemukakan pendapat antar sesama anggota sehingga terjalin hubungan sosial dengan baik.

\section{METODE}

Metode yang digunakan dalam penelitian ini adalah metode deskriptif. Hadari Nawawi (2007:67) mengungkapkan bahwa: "Metode deskriptif dapat diartikan sebagai prosedur pemecahan masalah yang diselidiki dengan menggambarkan/melukiskan keadaan subyek/obyek penelitian (seseorang, lembaga masyarakat dan lain-lain) pada saat sekarang berdasarkan fakta-fakta yang tampak atau sebagaimana adanya". Berdasarkan beberapa pengertian tersebut, dapat disimpulkan bahwa metode penelitian adalah suatu cara yang digunakan oleh peneliti dalam suatu penelitian untuk memecahkan permasalahan penelitian. Alasan penggunaan metode deskriptif adalah karena peneliti ingin memperoleh gambaran tentang pelaksanaan tindakan layanan informasi untuk meningkatkan pemahaman tentang nilai karakter, berdasarkan fakta atau kejadian yang sedang berlangsung di tempat penelitian.

Suatu metode penelitian, akan dapat digunakan dengan adanya dukungan dari bentuk penelitian, bentuk penelitian yang digunakan adalah penelitian tindakan (Action Research), yaitu salah satu strategi pemecahan masalah yang memanfaatkan tindakan nyata dan proses pengembangan kemampuan dalam mendeteksi dan memecahkan masalah. Penelitian tindakan adalah merupakan salah satu strategi yang memanfaatkan tindakan nyata dan proses pengembangan kemampuan dalam mendeteksi dan memecahakan masalah. Penelitian tindakan adalah suatu penelitian tindakan nyata yang memanfaatkan siklus atau suatu 
putaran perangkat-perangkat dari empat komponen, yaitu mulai dari perencanaan, pelaksanaan, pengamatan, dan refleksi yang bertujuan untuk mendeteksi, mengkaji, menganalisis, memperbaiki dan memecahkan suatu masalah. Dalam penelitian tindakan ini bersifat partisipasif, artinya bahwa peneliti terlibat dalam penelitian dan bersifat kolaboratif.

Subjek penelitian ini adalah mahasiswa program studi bimbingan dan konseling berjumlah 23 orang, sejumlah subjek ini diberikan tindakan yaitu layanan bimbingan kelompok melalui dua siklus penelitian. Teknik pengumpul data yang digunakan dalam penelitian adalah teknik komunikasi tidak langsung dengan alat pengumpul data angket, dan teknik observasi langsung dengan alat pengumpul data panduan observasi. Data angket dan panduan observasi dianalisis melalui rumus persentase sebagai berikut :

$\mathrm{X} \%=\underline{\mathrm{n}} \times 100 \%$

$\mathrm{N}$

Keterangan :

$\mathrm{X} \%=$ Hasil persentase

$\mathrm{n}$ = Jumlah alternatif jawaban

$\mathrm{N}$ = Jumlah responden

\section{HASIL DAN PEMBAHASAN}

\section{Gambaran Kemampuan Hubungan Sosial Sebelum Tindakan}

Untuk mengetahui gambaran kemampuan hubungan sosial mahasiswa dapat dilakukan dengan alat pengumpul data melalui angket. Analisis data yang digunakan dalam penelitian ini adalah data yang dikumpulkan pada setiap kegiatan penelitian. Sebelum hasil angket dideskripsikan maka terlebih dahulu hal yang harus dilakukan adalah dengan menentukan kategori hasil angket. Menetapkan kriteria tolok ukur sebagai pedoman untuk mentafsirkan hasil perhitungan data yang diperoleh. Tolok ukur ditetapkan dalam tiga tingkatan, yaitu kategori baik, cukup dan kurang.

Tabel 1. Tolok Ukur Kemampuan Hubungan Sosial 


\begin{tabular}{|c|c|}
\hline KATEGORI & $\%$ SKOR \\
\hline Baik & $66,67 \%-100 \%$ \\
\hline Cukup & $33,34 \%-66,66 \%$ \\
\hline Kurang & $00,00 \%-33,33 \%$ \\
\hline
\end{tabular}

Hasil penyebaran angket tentang kemampuan hubungan sosial mahasiswa sebelum diberikan tindakan layanan bimbingan kelompok pada mahasiswa program studi bimbingan dan konseling tahun akademik 2016/2017 memperoleh persentase secara umum 63,88 \% dengan kategori "cukup".

\section{Pelaksanaan Tindakan}

\section{a. Siklus 1}

1) Perencanaan Tindakan

Perencanaan yang dilakukan peneliti dengan tujuan agar pelaksanaan layanan bimbingan kelompok dapat berjalan dengan lancar. Hal yang pertama dilakukan peneliti adalah menyusun perangkat layanan salah satunya adalah menyusun satuan layanan bimbingan kelompok. Pada perencanaan ini tim peneliti untuk saling berdiskusi tentang hal-hal apa yang perlu dipersiapkan.

2) Pelaksanaan Tindakan

a) Pertemuan pertama

Pelaksanaan bimbingan kelompok pada pertemuan pertama masih terlihat kaku, dimana masing-masing anggota kelompok masih belum maksimal dalam menyesuaikan diri. Mereka masih terlihat bingung untuk mengikuti beberapa arahan dari pemimpin kelompok. Dari kekurangan ini dapat menjadi perhatian bagi pemimpin kelompok untuk memperbaikinya di pertemuan berikutnya.

b) Pertemuan Kedua

Pada pertemuan kedua ada beberapa siswa yang datang sedikit terlambat karena habis dari kantin dan mencari buku di perpustakaandan ada juga yang baru menyelesaikan tugas dari beberapa dosen, akan tetapi semuanya hadir untuk mengikuti kegiatan. Pada tahap awal pemimpin kelompok kembali menjelaskan mengenai kegiatan yang akan dilaksanakan dan membawa anggota kelompok dalam suasana keakraban agar anggota kelompok terlibat aktif dalam dinamika 
kelompok. Pemimpin kelompok meminta pada salah satu anggota untuk memimpin doa, anggota kelompok mulai aktif tetapi masih ada beberapa mahasiswa juga yang masih malu dan canggung dalam mengemukakan pendapat. Dalam memasuki tahap kegiatan anggota kelompok mengemukakan pendapatnya dan menjawab pertanyaan pemimpin kelompok. Mereka saling berbagi informasi mengenai kemampuan hubungan sosial yang dibahas. Pada tahap pengakhiran ini pemimpin kelompok mengakhiri kegiatan dan memberi kesimpulan tentang apa yang telah dibahas dan meminta peserta kelompok mengakhiri dengan doa.

\section{3) Observasi}

Setelah pertemuan pertama dan kedua dilaksanakan. Tim peneliti akan menganalisis hasil observasi. Observasi dalam penelitian ini dilakukan oleh anggota peneliti yang lain selama proses pelaksanaan layanan bimbingan kelompok. Observer melakukan penilaian berdasarkan pedoman observasi yang telah dibuat oleh peneliti. Data hasil pengamatan menunjukan bahwa siswa telah memanfaatkan kegiatan layanan bimbingan kelompok yang disajikan oleh peneliti. Meskipun pertemuan awal belum maksimal karena siswa masih dalam keadaan malu, takut dan ragu dengan bentuk kegiatan yang digunakan oleh peneliti, akan tetapi pada pertemuan kedua mulai terlihat peningkatannya walaupun tidak terlalu signifikan dan pertemuan kedua sudah terlihat anggota sudah bisa aktif dan semangat dalam melaksanakan setiap proses tahapan.

Hasil dari observasi aktivitas kegiatan layanan bimbingan kelompok untuk meningkatkan kemampuan hubungan sosial pada siklus I adalah sebagai berikut:

Grafik 1. Persentase Kegiatan Layanan Bimbingan kelompok Untuk Meningkatkan Kemampuan Hubungan Sosial Mahasiswa Siklus I

\section{Layanan Bimbingan Kelompok}

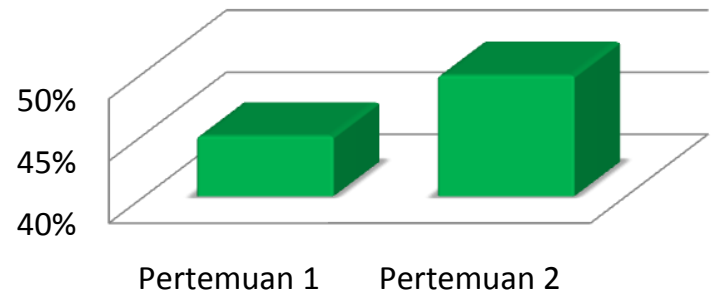


Berdasarkan grafik di atas dapat dijelaskan sebagai berikut :

a) Pertemuan pertama

Berdasarkan hasil observasi pada pertemuan pertama diperoleh nilai rata-rata dengan presentase 44,87\% untuk semua aktivitas layanan bimbingan kelompok dengan kategori cukup.

b) Pertemuan Kedua

Hasil observasi pada pertemuan kedua mengalami peningkatan yakni diperoleh presentase 49,75\%. Pemimpin kelompok semakin berusaha memperbaiki kualitas layanannya melalui beberapa aktivitas dan semangat yang diberikan kepada siswa untuk terlibat aktif dalam diskusi kelompok.

4) Refleksi

Berdasarkan hasil pertemuan pertama dan kedua kegiatan layanan bimbingan kelompok yang diuraikan di atas dapat diambil kesimpulan bahwa pelaksanaan bimbingan kelompok untuk meningkatkan kemampuan hubungan sosial siswa masih diperlukan untuk dilanjutkan ke siklus berikutnya, karena masih terdapat anggota kelompok yang masih ragu, bingung, dan terlihat kesulitan - kesulitan untuk menyesuaikan diri dengan dinamika kelompok. Dari hasil refleksi tersebut menjadi acuan bagi pemimpin kelompok untuk melaksanakan perbaikan-perbaikan dalam tindakan selanjutnya. Sebelum siklus ke II dilakukan terlebih dahulu pemimpin kelompok mendiskusikan kembali kepada kolaborator atau teman tim dalam penelitian.

\section{b. Siklus 2}

Pelaksanaan tindakan pada siklus II dapat dideskripsikan melewati beberapa tahapan yaitu :

1) Perencanaan (planning)

Sebelum pelaksanaan tindakan pada siklus kedua dimulai, peneliti mempersiapkan kembali beberapa hal yang digunakan dalam pelaksanaan layanan bimbingan kelompok. Partama-tama yang peneliti lakukan pada siklus kedua ini adalah membuat satuan layanan berdasarkan hasil refleksi pada siklus pertama. Merumuskan topik yang berkenaan dengan kemampuan hubungan sosial mahasiswa atau pemberian kelanjutan materi tentang hubungan sosialtersebut. 
Langkah selanjutnya adalah mempersiapkan pedoman observasi, dan menentukan waktu dan tempat dilaksanakannya layanan.

a) Tindakan.

Pemberian tindakan layanan bimbingan kelompok pada siklus II dilaksanakan melalui 2 kali pertemuan, yaitu pada hari Senin, 4 September 2017 dan hari Senin, 11 September 2017. Adapun tindakan-tindakan yang dilakukan pada siklus II dapat diuraikan sebagai berikut :

(1) Pemimpin kelompok membuka kembali layanan bimbingan kelompok dengan melihat kehadiran semua anggota kelompok. Pada pertemuan pertama dan kedua semua anggota kelompok hadir tepat waktu sebagaimana yang telah disepakati pada pertemuan pada siklus sebelumnya.

(2) Pemimpin kelompok lebih semangat dari pertemuan sebelumnya dan meningkatkan pemberian motivasi agar semua anggota kelompok bersedia mengikuti kegiatan dengan semangat.

(3) Pemimpin kelompok kembali menjalin keakraban dengan anggota kelompok agar suasana menjadi lebih hangat dan menyenangkan.

(4) Pemimpin kelompok menjelaskan kembali pengertian, tujuan, dan manfaat bimbingan kelompok.

(5) Pemimpin kelompok menguraikan manfaat dari layanan bimbingan kelompok yang dilaksanakan.

(6) Pemimpin kelompok menyampaikan topik yang akan dibahas.

(7) Pemimpim kelompok memberikan kesempatan kepada anggota untuk membahas topik yang disampaikan.

(8) Pemimpin kelompok memberikan motivasi kepada semua anggota kelompok untuk terlibat dalam pembahasan topik.

(9) Pemimpin kelompok menjembatani jika terjadinya perbedaan pendapat.

(10) Pemimpin kelompok memberikan kesempatan kepada masing-masing anggota untuk memberikan tanggapan terhadap pelaksanaan bimbingan kelompok.

(11) Pemimpin kelompok mengakhiri kegiatan dengan mengucapkan terima kasih atas kehadiran semua anggota serta ditutupi dengan do'a bersama. 
b) Observasi

Proses penilaian terhadap pelaksanaan layanan bimbingan kelompok tetap berjalan seiring pelaksanaan layanan bimbingan kelompok yang dilaksanakan. Penilaian masih dilakukan oleh kolaborator yaitu tim peneliti yang lain. Hasil observasi menunjukkan bahwa pelaksanaan layanan bimbingan kelompok semakin meningkatkan, tingkat keaktifan anggota dalam mengikuti layanan semakin baik. Begitu juga dengan pemimpin kelompok yang semakin berupaya meningkatkan semangat mahasiswa untuk terlibat dalam membahas topik yang disampaikan.

Pada tahap-tahap di pertemuan sebelumnya para anggota masih terlihat enggan untuk mengikuti kegiatan layanan bimbingan kelompok. Akan tetapi di siklus kedua ini, semua anggota kelompok sudah semakin terlihat keaktifannya dalam mengikuti beberapa arahan dari pemimpin kelompok. Lebih jelas pada siklus kedua ini berdasarkan observasi yang dilakukan oleh kolabolator dalam layanan bimbingan kelompok untuk meningkatkan kemampuan hubungan sosial dapat dijelaskan dalam grafik 2 sebagai berikut :

Grafik 2. Persentase Kegiatan Layanan Bimbingan Kelompok Pada Siklus II

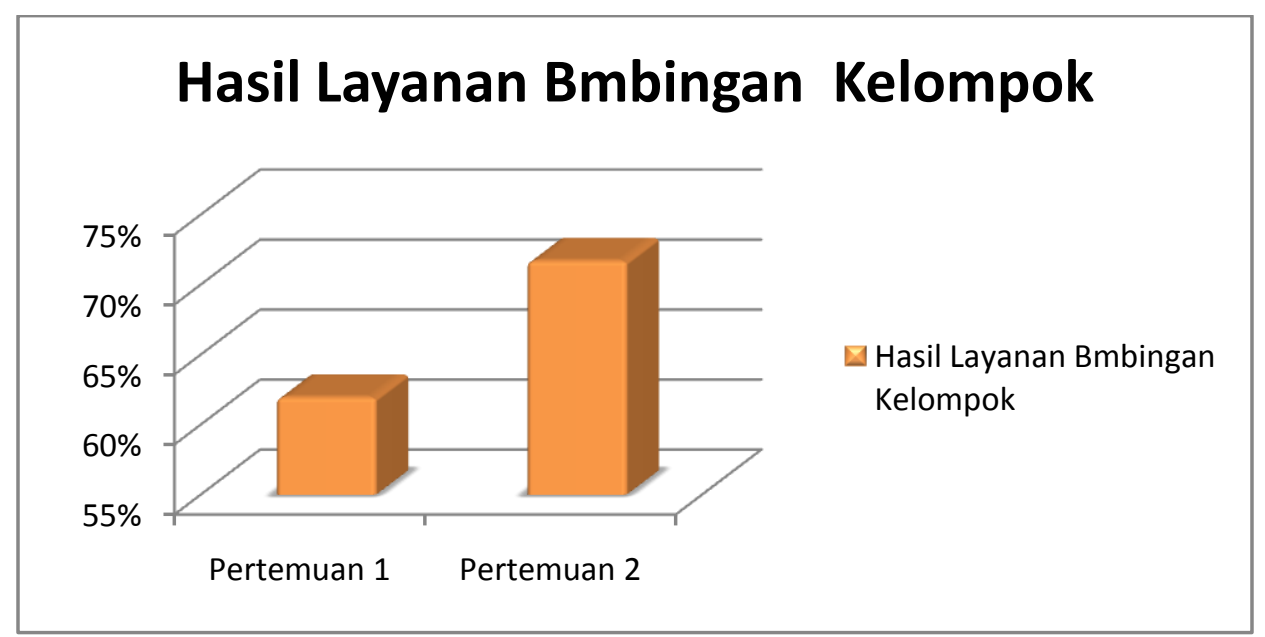

Beradasarkan grafik di atas dapat dijelaskan sebagai berikut :

1) Pertemuan pertama

Berdasarkan hasil observasi pada siklus ke II semua pelaksanaan tindakan baik itu pertemuan pertama maupun pertemuan kedua mengalami kenaikan. Untuk pertemuan pertama diperoleh nilai rata-rata hasil dari observasi dengan presentase 
61,95\% untuk pemimpin kelompok dengan kategori baik, sehingga bisa diambil kesimpulan bahwa kegiatan layanan bimbingan kelompok untuk meningkatkan kemampuan hubungan sosial siswa sudah berjalan dengan baik. Pemimpin dan anggota kelompok sudah semaksimal mungkin untuk melaksanakan beberapa tahapan.

2) Pertemuan Kedua

Hasil observasi pada pertemuan kedua proses layanan dapat disimpulkan sudah semakin baik, sehingga hasil observasi layanan bimbingan mengalami kenaikan dengan presentase 71,70\% dalam kategori baik. Hal ini dapat diinterpretasikan bahwa layanan bimbingan kelompok yang dilaksanakan oleh peneliti sudah berjalan dengan baik. Hal ini tampak pada aktivitas-aktivitas kegiatan yang dilakukan semua anggota kelompok yang cukup baik dalam melibatkan diri untuk mengemukakan pendapat dan aktif dalam pembahasan masalah yang menjadi topik bahasan. Dari beberapa anggota kelompok sudah menunjukkan semangat dalam mengikuti kegiatan kelompok. Para anggota sudah mulai berani dan percaya diri dalam menyampaikan idenya masing-masing.

3) Refleksi

Dari hasil observasi pertemuan pertama dan kedua dalam siklus kedua ini dapat disimpulkan bahwa pelaksanaan layanan bimbingan kelompok untuk meningkatkan aktivitas belajar siswa berjalan dengan baik. Semua anggota sudah menunjukkan keaktifannya dalam melaksanakan layanan bimbingan kelompok . Anggota kelompok saling memberikan tanggapan mengenai apa yang telah dibahas. Angggota kelompok sudah sudah semaksimal mungkin untuk melibatkan diri dalam diskusi kelompok.

\section{Kemampuan Hubungan Sosial Setelah Tindakan}

Setelah pelaksanaan layanan bimbingan kelompok melalui dua siklus penelitian, maka. akan dilihat kembali gambaran kemampuan hubungan sosial masiswa. Untuk mengetahui gambara kemampuan hubungan sosial mahasiswa tersebut, peneliti menyebarkan kembali angket tentang hubungan sosial setelah tindakan. Hasil penyebaran angket tentang kemampuan hubungan sosial setelah diberikan tindakan pada mahasiswa program studi bimbingan dan konseling 
Tahun Akademik 2016/2017 IKIP-PGRI Pontianak memperoleh persentase secara umum 72,05 \% dengan kategori "BAIK". Sehingga dapat disimpulkan bahwa terdapat peningkatan skor kemampuan hubungan sosial mahasiswa sebelum dan sesudah tindakan sebanyak $8,17 \%$.

Upaya meningkatkan kemampuan hubungan sosial di perguruan tinggi merupakan langkah yang sangat baik untuk dilakukan, dalam rangka mempersiapkan bahwa agar lebih memahami pentingnya peningkatan hubungan sosial, sehingga mampu menyesuaikan diri dimanapun ia berada. Mahasiswa sebagai mahluk sosial, memiliki dorongan ingin tahu, ingin maju dan berkembang, salah satu strateginya melalui hubungan sosial. Hubungan sosial yang diciptakan merupakan kebutuhan yang mutlak bagi kehidupan manusia. Hubungan sosial memberikan sesuatu kepada orang lain dengan kontak tertentu atau dengan mempergunakan sesuatu alat komunikasi. Banyak hubungan sosial yang terjadi dan berlangsung tetapi kadang-kadang tidak tercapai kepada sasaran tentang hubungan apa yang diinginkan. Dimungkinkan adanya komunikasi yang baik antara pemberi pesan dan penerima pesan kalau terjalin persesuaian diantara keduanya.

Layanan bimbingan kelompok untuk meningkatkan kemampuan hubungan sosial pada mahasiswa dimaksudkan agar individu tersebut memiliki pandangan hidup sebagai suatu keseluruhan, cenderung bersifat realistis dan objektif terhadap diri sendiri maupun orang lain, peduli terhadap faham-faham abstrak seperti keadilan sosial, mampu mengintegrasikan nilai-nilai yang bertentangan, toleran terhadap ambiguitas, peduli akan pemenuhan diri (Self full fillment), ada keberanian untuk menyelesaikan konflik internal, resfek terhadap terhadap sikap orang lain, saling menghormati dan menghargai orang lain, mematuhi serta menjalankan norma dan nilai yang berlaku, serta berinteraksi sosial antara sesama. Tohirin (2007:170) mengemukakan bimbingan kelompok adalah suatu cara memberikan bantuan kepada individu melalui kegiatan kelompok. Bimbingan kelompok merupakan sarana untuk membantu dan menunjang perkembangan masing-masing individu dalam mencapai perkembangan yang optimal, dan diharapkan dapat mengambil manfaat dari pengalaman pendidikan ini bagi dirinya 
sendiri. Tohirin (2007:170) mengemukakan bimbingan kelompok adalah suatu cara memberikan bantuan kepada individu melalui kegiatan kelompok. Bimbingan kelompok merupakan sarana untuk membantu dan menunjang perkembangan masing-masing individu dalam mencapai perkembangan yang optimal, dan diharapkan dapat mengambil manfaat dari pengalaman pendidikan ini bagi dirinya sendiri.

Melalui layanan bimbingan kelompok mahasiswa dapat berkomunikasi, berinteraksi dan mengemukakan pendapat antar sesama anggota sehingga terjalin hubungan sosial dengan baik. Penelitian ini diperkuat dengan penelitian yang relevan oleh Ratih Novita Sari dkk (2010) Hasil penelitian ini ditunjukkan dari hasil pretest dan posttest yang diperoleh $\mathrm{Z}$ hitung $=-3,18$ dan $\mathrm{Z}$ tabel, dengan nilai $\alpha=5 \%$ adalah 1,645. Karena $\mathrm{Z}$ hitung $<\mathrm{Z}$ tabel, maka Ho ditolak dan Ha diterima, artinya terdapat peningkatan interaksi Sosial yang signifikan setelah diberikan layanan bimbingan kelompok. Melalui layanan bimbingan kelompok mahasiswa dapat berkomunikasi, berinteraksi dan mengemukakan pendapat antar sesama anggota sehingga terjalin hubungan sosial dengan baik. Hasil penelitian Merry Andani (2016) menunjukkan bahwa interaksi sosial siswa mengalami peningkatan setelah pemberian layanan bimbingan kelompok. Hal ini ditunjukkan dari hasil uji pretest dan posttest yang diperoleh Zhitung $=-3,06$ dan Ztabel =1,645. Karena Zhitung < Ztabel maka, Ho ditolak dan Ha diterima. Kesimpulan penelitian ini adalah layanan bimbingan kelompok dapat dipergunakan untuk meningkatkan interaksi sosial pada siswa kelas VIII di SMP Negeri 4 Natar, Lampung Selatan Tahun Ajaran 2016/2017.

\section{SIMPULAN}

Berdasarkan hasil penelitian yang telah dilaksanakan dalam penelitian ini dapat disimpulkan bahwa kemampuan hubungan sosial mahasiswa Program Studi Bimbingan dan Konseling Tahun Akademik 2016/2017 dapat ditingkatkan melalui layanan layanan bimbingan kelompok. Berdasarkan simpulan utama dapat dijabarkan menjadi tiga simpulan sebagai berikut: 
1. Kemampuan hubungan sosial mahasiswa sebelum diberikan layanan bimbingan kelompok rata-rata berada pada kategori cukup $(63,88 \%)$. Hal ini menunjukkan bahwa kemampuan hubungan sosial mahasiswa masih belum maksimal, siswa belum cukup mampu meningkatkan hubungan sosialnya dengan baik.

2. Proses layanan bimbingan kelompok berjalan dengan baik melalui 2 siklus penelitian, dengan beberapa tahapan yaitu : perencanaan layanan, pelaksanaan layanan, observasi dan refleksi.

3. Kemampuan hubungan sosial mahasiswa setelah mendapatkan layanan bimbingan kelompok mengalami peningkatan sebesar 8,17 \% sehingga menjadi $72,05 \%$. Hal ini menunjukkan bahwa kemampuan hubungan sosial mahasiswa sudah lebih baik dari yang sebelum diberikan layanan bimbingan kelompok.

\section{DAFTAR PUSTAKA}

Abu Ahmadi. (2011), Psikologi Sosial, Bandung: Rosda Karya Remaja.

Dede Rahmat H dan Aip Badrujaman. (2012), Penelitian Tindakan dalam Bimbingan dan Konseling. PT. Indeks: Jakarta.

Driyarkara. (1981), Tentang Pendidikan. Jakarta: Pustaka Rakyat.

Merry Andani. (2016), Penggunaan Layanan Bimbingan Kelompok Untuk Meningkatkan Interaksi Sosial. Jurnal Bimbingan dan Konseling (ALIBKIN). Vol 6 Nomor 2.

Suharsimi Arikunto. (2007), Prosedur Penelitian Suatu Pendekatan Praktek. Jakarta: Bina Aksara.

Sumadi Suryabrata. (2010), Metodologi Penelitian. Jakarta: Raja Grafindo Persada.

Sukiman. (2011), Penelitian Tindakan Bimbingan dan Konseling. Yogjakarta: Tiara Wacana.

Tohirin. (2007), Bimbingan dan Konseling di Sekolah dan Madrasah. Jakarta: PT Raja Gravindo Persada. 
Wibowo. (2005), Bimbingan Konseling Kelompok Perkembangan. Semarang: Unnes Press.

Zainal Aqib. (2011), Ihktisar Bimbingan dan Konseling. Jakarta: Rineka Cipta. 